\title{
The Renal Handling of Insulin*
}

\author{
M. J. Chamberlain † and L. Stim mLer \\ (From the Department of Experimental Pathology and Institute of Child Health, The \\ University of Birmingham, England)
}

Summary. The renal handling of insulin was studied by insulin immunoassay in arterial blood, renal venous blood, and urine of fasting patients with normal renal function and in peripheral venous blood and urine of normal subjects and patients with renal disease before and after an oral glucose load. A renal arteriovenous insulin concentration difference of approximately $29 \%$ was found and suggests that in normal subjects renal insulin clearance is significantly in excess of glomerular filtration rate. The insulin excreted in the urine of normal individuals at no time exceeded $1.5 \%$ of the load filtered at the glomerulus. This contrasts with the finding of a urinary insulin clearance approaching glomerular filtration rate in patients with severely impaired renal tubular function.

It is suggested that insulin is normally filtered at the glomerulus and then almost completely reabsorbed or destroyed in the proximal tubule. If reabsorption occurs, as seems more likely, reabsorbed insulin does not return to the renal vein and is presumably utilized in renal metabolism together with insulin taken up directly from the blood.

Caution is advised in the use of urinary insulin concentration or excretion as an index of serum insulin level or insulin secretion because a very small and variable proportion of filtered insulin appears in the urine in normal subjects, and major changes in urinary insulin excretion may arise as a result of minor tubular defects.

\section{Introduction}

There is accumulating evidence, reviewed by O'Brien and Sharpe (1), that the influence of the kidney on carbohydrate metabolism may be due to an important role in insulin metabolism in addition to its function as an organ of glucose conservation and gluconeogenesis. There are, however, a number of contradictory observations to be reconciled. There is the widespread clinical impression, albeit much disputed $(2,3)$, that insulin requirements of diabetic patients may fall with the onset of renal failure as do those of rats with alloxan diabetes after the induction of nephrosis (4). On the other hand, patients developing re-

* Submitted for publication November 10, 1966; accepted February 17, 1967.

$\dagger$ Address requests for reprints to Dr. M. J. Chamberlain, Dept. of Experimental Pathology, The University of Birmingham Medical School, Birmingham 15, England. nal failure may then, for the first time, show a diabetic type of glucose tolerance curve, and recently it has been shown that the carbohydrate intolerance of chronic renal failure may be abolished by repeated hemodialysis $(5,6)$. The amount of insulin appearing in the urine of experimental animals after perfusion experiments is much less than that expected for a protein of the same molecular weight $(7,8)$. Human urinary insulin excretion was similarly less than theoretically expected in the recent studies of urinary immunoreactive insulin by Jørgensen (9) and McArthur and Stimmler (10), although neither was accompanied by serum studies. These workers imply, and others have claimed more directly (11), that urinary insulin may reflect serum levels and hence urinary insulin studies may become useful clinically. We report a series of studies on the renal handling of insulin in the human, both 


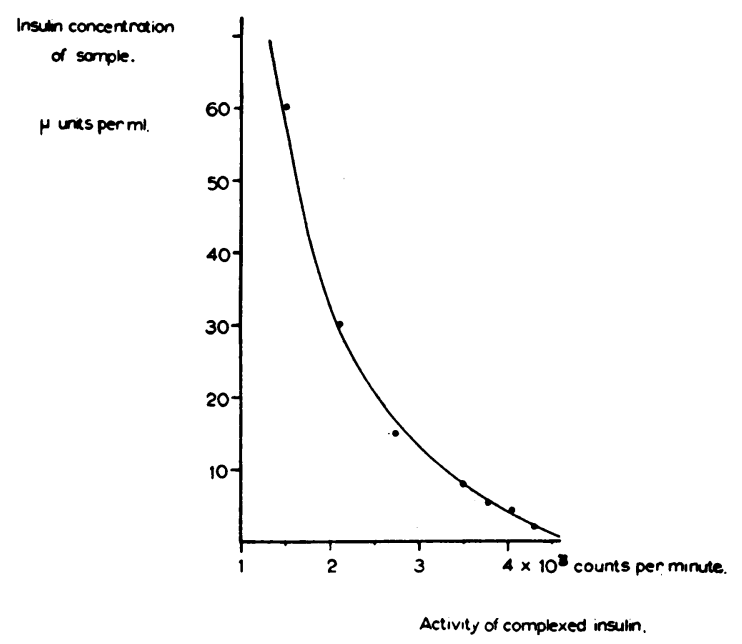

Fig. 1. PART OF A WORKING STANDARD CURVE FOR INSULIN ASSAY. The curve is calibrated directly in terms of the activity of the precipitated insulin-insulin antibody complex resulting from the reaction of fixed amounts of radioinsulin and insulin antibody with samples of standard insulin solutions.

in subjects with normal renal function and in patients with well-defined renal abnormalities.

\section{Methods}

Seventeen subjects with normal renal function and seven patients with renal disease were studied. All had a normal fasting blood glucose, and glycosuria was present in none of the subjects with normal renal function.

Insulin assay. Immunoreactive insulin was measured in serum and urine by the method of Morgan and Lazarow
(12) modified by the use of iodoinsulin- ${ }^{125} I$ in place of iodoinsulin- ${ }^{181} \mathrm{I}$. Specimens were frozen immediately after collection and stored at $-20^{\circ} \mathrm{C}$ until the assay was performed, never more than 1 week later. All assays were carried out at a buffered $\mathrm{pH}$ of 8.5. All estimations were done in duplicate or triplicate, and replicate analyses had a standard deviation of $1.8 \mu \mathrm{U}$ per ml over the range 0 to $30 \mu \mathrm{U}$ per $\mathrm{ml}$. The amount of radioinsulin added as tracer was $1.25 \mu \mathrm{U}$, and, since $100-\mu 1$ samples of serum and urine were assayed, this was competing for insulin antibody with 0 to $3.0 \mu \mathrm{U}$ of endogenous insulin in the case of urine assays and 0 to $10.0 \mu \mathrm{U}$ in the case of serum assays. A new standard curve was determined as part of each separate batch of assays. Figure 1 shows a typical working standard curve.

With urine samples a preliminary assay was carried out on the undiluted specimen, and, in the few cases where the insulin concentration exceeded $30 \mu \mathrm{U}$ per ml, the definitive assay was performed after suitable dilution of the urine to bring the final concentration into the range 0 to $30 \mu \mathrm{U}$ per ml. Known amounts of insulin were added to urine to produce final concentrations throughout the range encountered in the experiments. Assay of these urines gave a mean recovery of $96 \%$. Throughout the range of concentrations up to $50 \mu \mathrm{U}$ per $\mathrm{ml}$ the assay consistently underestimated the true concentration by 15 to $24 \%$, whereas at higher concentrations up to 130 $\mu \mathrm{U}$ per $\mathrm{ml}$ there was a tendency to overestimate by a similar amount.

Glucose estimation. Plasma glucose was measured by the glucose oxidase method of Middleton and Griffiths (13).

Glomerular filtration rate was measured as endogenous creatinine clearance.

Renal arteriovenous insulin differences and insulin clearance. Renal arteriovenous insulin differences were measured in 12 patients who were undergoing diagnostic

TABLE I

Arterial renal venous and urinary insulin concentrations in fasting patients with normal renal function

\begin{tabular}{|c|c|c|c|c|c|c|c|c|c|}
\hline Patient & Sex & Age & $\underset{\text { Ansulerial }}{\text { Ans }}$ & $\begin{array}{l}\text { Renal } \\
\text { venous } \\
\text { insulin }\end{array}$ & $\stackrel{a-v}{\text { difference* }}$ & $\begin{array}{l}\text { Insulin } \\
\text { extraction } \\
\text { ratio }\end{array}$ & $\begin{array}{l}\text { Urinary } \\
\text { insulin }\end{array}$ & $\begin{array}{l}\text { Urine } \\
\text { flow } \\
\text { rate }\end{array}$ & $\begin{array}{l}\text { Urinary } \\
\text { insulin } \\
\text { clearance }\end{array}$ \\
\hline & & years & & $\mu U / m l$ & & & $\mu U / m l$ & & $\mathrm{ml} / \mathrm{min}$ \\
\hline 1 & M & 53 & 25.5 & 15.7 & 9.8 & 0.38 & 4.4 & 2.5 & 0.43 \\
\hline 2 & $\mathbf{M}$ & 65 & 6.3 & 4.9 & 1.4 & 0.22 & 2.0 & 1.2 & 0.39 \\
\hline 3 & $\mathbf{M}$ & 56 & 29.8 & 14.8 & 15.0 & 0.50 & 2.8 & 0.6 & 0.06 \\
\hline 4 & M & 41 & 6.9 & 5.8 & 1.1 & 0.16 & 0.6 & 4.4 & 0.38 \\
\hline 5 & $\mathrm{~F}$ & 13 & 14.5 & 9.1 & 4.6 & 0.31 & 34.0 & 0.2 & 0.46 \\
\hline 6 & $F$ & 24 & 6.4 & 5.5 & 0.9 & 0.14 & 1.8 & 0.6 & 0.17 \\
\hline 7 & $\mathbf{M}$ & 48 & 12.6 & 8.0 & 4.6 & 0.37 & 4.4 & 0.8 & 0.29 \\
\hline 8 & M & 48 & 17.7 & 10.0 & 7.7 & 0.43 & 2.0 & 5.2 & 0.58 \\
\hline 9 & $\mathbf{M}$ & 55 & 12.7 & 11.6 & 1.1 & 0.09 & 5.2 & 1.5 & 0.61 \\
\hline 10 & $\mathbf{M}$ & 42 & 26.4 & 17.0 & 9.4 & 0.36 & & & \\
\hline 11 & M & 30 & 5.9 & 4.0 & 1.9 & 0.32 & & & \\
\hline 12 & M & 56 & 5.0 & 3.6 & 1.4 & 0.28 & & & \\
\hline \multicolumn{2}{|c|}{ Mean values } & 44 & 14.1 & 9.3 & 4.8 & $\begin{array}{r}0.29 \\
\mathrm{SD} \pm 0.12\end{array}$ & 6.1 & 1.2 & $\begin{array}{r}0.37 \\
S D \pm 0.18\end{array}$ \\
\hline
\end{tabular}

* Arteriovenous difference. 
cardiac catheterization, which required the presence of a venous catheter and an arterial catheter or needle. The renal studies occupied less than 5 minutes and did not significantly lengthen or increase the risk of the diagnostic procedure.

Ten male and two female patients whose ages ranged from 13 to 65 years were studied. No patient had a history of renal disease, none had a blood urea greater than $35 \mathrm{mg}$ per $100 \mathrm{ml}$, and none had pyuria, proteinuria, or glycosuria. Glomerular filtration rate was measured in six of these patients and found to be greater than $70 \mathrm{ml}$ per minute per $1.72 \mathrm{~m}^{2}$. All had been fasting for at least 8 hours at the time of the study.

A catheter was passed into the left renal vein under fluoroscopic control and its position confirmed by the injection through it of $2 \mathrm{ml}$ of $85 \%$ Hypaque (diatrizoate). Blood for insulin estimation was withdrawn simultaneously through the venous catheter and from a convenient arterial site.

In nine of the above patients an accurately timed specimen of urine for insulin estimation was obtained, by voluntary voiding, over a period the midpoint of which was the time of arterial and venous blood sampling.

\section{Results}

Renal arteriovenous insulin differences in the twelve fasting patients with normal renal function are summarized in Table I. The concentration of insulin in renal venous blood was invariably lower than in the corresponding arterial blood. The mean arterial insulin level was 14.1 and the mean venous level $9.3 \mu \mathrm{U}$ per $\mathrm{ml}$. The magnitude of the arteriovenous difference is related to arterial insulin level for the 12 patients in Figure 2. The correlation coefficient is 0.95 , and the calculated regression line has been drawn and indicates that within the limits of the study renal extraction of insulin is proportional to arterial blood concentra- tion. The regression line is too dependent on points derived from low serum insulin levels, at which the assay is least reliable, for other conclusions to be drawn from it.

The mean renal insulin extraction ratio (arteriovenous difference/arterial level) was 0.29 (standard deviation \pm 0.12 ) as shown in Table I. Assuming a normal renal plasma flow of approximately $650 \mathrm{ml}$ per minute, this would imply a renal insulin extraction of the order of $190 \mathrm{ml}$ per minute. This contrasts with the over-all mean value of $0.37 \mathrm{ml}$ per minute (standard deviation \pm 0.18 ) for the urinary insulin clearance calculated from urinary to arterial insulin concentration ratio and urine flow rate.

The effect of variations in serum insulin concentration and of renal abnormalities. We wished to determine the effect on its renal handling of variations in the level of serum insulin and also the abnormalities of insulin handling in patients with various renal disorders. For neither of these studies was it thought justifiable to perform repeated arterial punctures let alone renal vein catheterization. Therefore, five normal adults, listed in Table II, and six patients with well-defined renal abnormalities, listed in Table III, were investigated as follows.

Insulin concentration was measured in forearm venous blood and in urine samples obtained immediately before and at 30-minute intervals after a 50-g oral glucose load had been given to fasting subjects. All blood samples were assayed for glucose in addition to insulin. The importance of complete bladder emptying was stressed, and urine collections were carefully timed. The urine

TABLE II

Urinary clearance of insulin in fasting healthy volunteers

\begin{tabular}{|c|c|c|c|c|c|c|c|}
\hline Subject & Sex & Age & $\begin{array}{l}\text { Peripheral } \\
\text { venous } \\
\text { insulin }\end{array}$ & $\begin{array}{l}\text { Urinary } \\
\text { insulin }\end{array}$ & $\begin{array}{l}\text { Urinary } \\
\text { insulin } \\
\text { clearance }\end{array}$ & $\begin{array}{c}\text { GFR* } \\
\text { as creatinine } \\
\text { clearance }\end{array}$ & $\begin{array}{c}\begin{array}{c}\text { Urinary } \\
\text { insulin } \\
\text { clearance }\end{array} \\
\text { GFR }\end{array}$ \\
\hline & & years & \multicolumn{2}{|c|}{$\mu U / m l$} & \multicolumn{2}{|c|}{$\operatorname{ml} / \min$} & $\%$ \\
\hline $\begin{array}{l}13 \\
14 \\
15 \\
16 \\
17 \\
17\end{array}$ & $\begin{array}{l}M \\
\mathbf{F} \\
M \\
M \\
F\end{array}$ & $\begin{array}{l}43 \\
32 \\
29 \\
35 \\
43\end{array}$ & $\begin{array}{r}8.0 \\
9.0 \\
16.0 \\
12.0 \\
15.0 \\
14.0\end{array}$ & $\begin{array}{l}8.0 \\
2.0 \\
8.8 \\
4.0 \\
2.8 \\
2.0\end{array}$ & $\begin{array}{l}1.20 \\
0.29 \\
0.35 \\
0.66 \\
0.22 \\
0.10\end{array}$ & $\begin{array}{r}158 \\
90 \\
128 \\
130 \\
106\end{array}$ & $\begin{array}{l}0.76 \\
0.32 \\
0.27 \\
0.51 \\
0.21 \\
0.09\end{array}$ \\
\hline Mean & & & 12.3 & 4.9 & 0.47 & 126 & 0.36 \\
\hline
\end{tabular}

* Glomerular filtration rate. 
TABLE III

Details of patients with renal disease in whom renal handling of insulin was studied

\begin{tabular}{|c|c|c|c|c|c|c|c|c|c|}
\hline Patient & Sex & Age & Renal disease & GFR & $\begin{array}{c}\text { Serum } \\
\text { urea }\end{array}$ & $\begin{array}{l}\text { Protein- } \\
\text { uria }\end{array}$ & $\underset{\text { uria }}{\text { Glycos- }}$ & $\underset{\text { protein* }}{\text { Tubular }}$ & $\begin{array}{l}\text { Amino- } \\
\text { aciduria }\end{array}$ \\
\hline & & years & & $\mathrm{ml} / \mathrm{min}$ & $\underset{100 \mathrm{ml}}{\mathrm{mg} /}$ & $\mathrm{g} / 24 \mathrm{hr}$ & & & \\
\hline 18 & $\mathbf{M}$ & 40 & Adult Fanconi syndrome & 40 & 46 & 6.5 & + & + & + \\
\hline 19 & $\mathbf{M}$ & 46 & Adult Fanconi syndrome & 38 & 60 & 4.0 & + & + & + \\
\hline 20 & $\mathbf{M}$ & 49 & Recovering acute tubular necrosis & 24 & 100 & 1 & - & + & - \\
\hline 21 & $\mathbf{M}$ & 17 & Chronic glomerulonephritis & 4 & 330 & 3.0 & + & - & - \\
\hline 22 & $\mathbf{M}$ & 34 & Nephrotic syndrome & 80 & 40 & 20 & - & - & - \\
\hline 23 & $\mathrm{~F}$ & 16 & Nephrotic syndrome & 27 & 70 & 15 & - & - & - \\
\hline 24 & $\mathbf{M}$ & 50 & Cadmium nephropathy & 69 & 39 & 1 & - & + & + \\
\hline
\end{tabular}

* The low molecular weight proteinuria characteristic of renal tubular disorders (14).

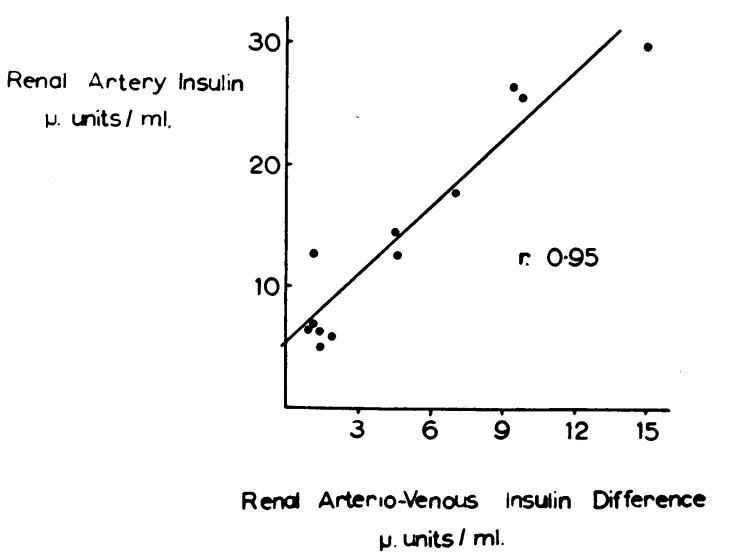

Fig. 2. The RELAtionship OF RENAL arteriovenous INSULIN CONCENTRATION DIFFERENCE TO ARTERIAL INSULIN LEVEL IN 12 FASTING PATIENTS WITH NORMAL RENAL FUNCTION. The calculated regression line has been drawn.

corresponding to the fasting blood sample was collected over the 30 minutes before the glucose was given, and the test was continued for 120 or 150 minutes afterwards. Urinary insulin clearance was calculated for each 30-minute period during the test using the serum insulin concentration at the midpoint of the collection period and the insulin concentration in each 30-minute volume of urine. The values for urinary insulin clearance obtained in this way are not comparable with those obtained in normal subjects using arterial blood, as in the studies described above, because at any given time insulin concentration in forearm venous blood is almost certainly lower than in arterial blood $(15,16)$. The expression for urinary clearance (concentration of insulin in urine/concentration of insulin in serum $\times$ urine flow rate) is such that urinary clearance calculated from venous blood will tend to be falsely high. However, comparisons between normal subjects and patients with renal disease may still be valid if urinary clearance is similarly calculated in both groups. Results were obtained in five normal adults, three males and two females, listed in Table II, and in six patients with well-defined renal abnormalities, listed in Table III. In a seventh patient, a man with cadmium nephropathy, the only study possible was measurement of the 24-hour urinary excretion of insulin.

Effect of variation in serum insulin level. In the tests on normal individuals, oral administration of $50 \mathrm{~g}$ of glucose produced the expected rise in blood glucose with a return to fasting levels within 150 minutes. The response of serum insulin to this stimulus resulted, in each case, in a curve closely parallel to that for blood glucose.

Urinary insulin concentration rose during each

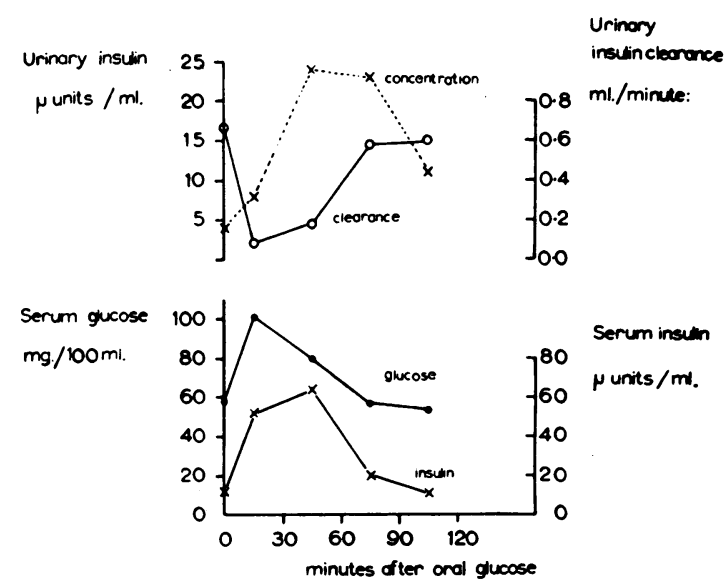

Fig. 3. VARIATIONS IN URINARY INSULIN CONCENTRATION, URINARY INSULIN CLEARANCE, SERUM GLUCOSE, AND SERUM INSULIN AFTER AN ORAL 50-G GLUCOSE LOAD IN A FASTING NORMAL INDIVIDUAL (SUBJECT 16, TABLE II). 
TABLE IV

Responses of, normal subjects to a 50-g oral glucose load

\begin{tabular}{|c|c|c|c|c|c|c|c|}
\hline Subject & $\begin{array}{l}\text { Time after } \\
\text { oral glucose }\end{array}$ & $\begin{array}{l}\text { Blood } \\
\text { glucose }\end{array}$ & $\begin{array}{l}\text { Serum } \\
\text { insulin }\end{array}$ & $\begin{array}{l}\text { Urinary } \\
\text { insulin }\end{array}$ & $\begin{array}{c}\text { Urine } \\
\text { flow rate }\end{array}$ & $\begin{array}{l}\text { Insulin } \\
\text { U/S } \\
\text { ratio }\end{array}$ & $\begin{array}{l}\text { Urinary } \\
\text { insulin } \\
\text { clearance }\end{array}$ \\
\hline & $\min$ & $\mathrm{mg} / 100 \mathrm{ml}$ & \multicolumn{2}{|c|}{$\boldsymbol{\mu} U / \boldsymbol{m l}$} & $m l / m i n$ & & $m l / m i n$ \\
\hline 13 & $\begin{array}{c}0 \\
0-30 \\
30-60 \\
60-90 \\
90-120 \\
120-150\end{array}$ & $\begin{array}{r}98 \\
104 \\
101 \\
82 \\
71 \\
74\end{array}$ & $\begin{array}{r}8 \\
21 \\
32 \\
21 \\
9 \\
7\end{array}$ & $\begin{array}{r}8.0 \\
9.0 \\
20.0 \\
22.0 \\
14.0 \\
17.0\end{array}$ & $\begin{array}{l}1.20 \\
1.5 \\
0.8 \\
0.81 \\
1.04 \\
1.03\end{array}$ & $\begin{array}{l}1.00 \\
0.45 \\
0.63 \\
1.10 \\
1.40 \\
2.26\end{array}$ & $\begin{array}{l}1.20 \\
0.68 \\
0.50 \\
1.10 \\
1.12 \\
2.33\end{array}$ \\
\hline 14 & $\begin{array}{c}0 \\
0-30 \\
30-60 \\
60-90 \\
90-120 \\
120-150\end{array}$ & $\begin{array}{l}61 \\
72 \\
81 \\
64 \\
74 \\
81\end{array}$ & $\begin{array}{r}9 \\
19 \\
22 \\
16 \\
29 \\
30\end{array}$ & $\begin{array}{l}2.0 \\
1.0 \\
1.0 \\
4.0 \\
5.0 \\
5.0\end{array}$ & $\begin{array}{l}1.33 \\
2.65 \\
3.58 \\
1.67 \\
1.03 \\
1.60\end{array}$ & $\begin{array}{l}0.29 \\
0.05 \\
0.05 \\
0.25 \\
0.17 \\
0.25\end{array}$ & $\begin{array}{l}0.38 \\
0.13 \\
0.18 \\
0.42 \\
0.18 \\
0.40\end{array}$ \\
\hline 15 & $\begin{array}{c}0 \\
0-30 \\
30-60 \\
60-90 \\
90-120 \\
120-150\end{array}$ & $\begin{array}{l}80 \\
97 \\
88 \\
53 \\
48 \\
60\end{array}$ & $\begin{array}{r}16 \\
43 \\
53 \\
25 \\
11 \\
8\end{array}$ & $\begin{array}{r}8.8 \\
9.0 \\
16.9 \\
17.0 \\
4.1 \\
4.0\end{array}$ & $\begin{array}{l}0.63 \\
0.77 \\
0.87 \\
1.10 \\
3.71 \\
1.35\end{array}$ & $\begin{array}{l}0.55 \\
0.21 \\
0.31 \\
0.68 \\
0.37 \\
0.50\end{array}$ & $\begin{array}{l}0.35 \\
0.16 \\
0.27 \\
0.75 \\
1.38 \\
0.68\end{array}$ \\
\hline 16 & $\begin{array}{l}0 \\
0-30 \\
30-60 \\
60-90 \\
90-120\end{array}$ & $\begin{array}{r}58 \\
101 \\
80 \\
57 \\
54\end{array}$ & $\begin{array}{l}12 \\
52 \\
64 \\
20 \\
11\end{array}$ & $\begin{array}{r}4.0 \\
8.0 \\
24.0 \\
23.0 \\
11.0\end{array}$ & $\begin{array}{l}2.00 \\
0.50 \\
0.47 \\
0.50 \\
0.67\end{array}$ & $\begin{array}{l}0.33 \\
0.15 \\
0.38 \\
1.15 \\
1.00\end{array}$ & $\begin{array}{l}0.67 \\
0.08 \\
0.18 \\
0.58 \\
0.57\end{array}$ \\
\hline 17 & $\begin{array}{c}0 \\
0-30 \\
30-60 \\
60-90 \\
90-120 \\
120-150\end{array}$ & $\begin{array}{r}38 \\
70 \\
102 \\
68 \\
65 \\
63\end{array}$ & $\begin{array}{r}15 \\
65 \\
103 \\
17 \\
35 \\
23\end{array}$ & $\begin{array}{l}2.8 \\
2.8 \\
3.6 \\
3.6 \\
4.5 \\
2.6\end{array}$ & $\begin{array}{r}1.53 \\
1.73 \\
7.60 \\
14.40 \\
8.10 \\
2.44\end{array}$ & $\begin{array}{l}0.18 \\
0.02 \\
0.03 \\
0.05 \\
0.13 \\
0.11\end{array}$ & $\begin{array}{l}0.22 \\
0.06 \\
0.23 \\
0.72 \\
1.05 \\
0.27\end{array}$ \\
\hline
\end{tabular}

test; changes in serum and urinary insulin showed a rough parallelism, but there was no simple relationship between them. There was a suggestion that urinary insulin clearance fell from fasting levels to reach a minimum when serum insulin concentration was near its maximum, but the possible errors of the assay at low levels of serum and urinary insulin make it doubtful whether this is a valid observation. Although urinary insulin clearance remained of the same order of magnitude, the suggestion of variation with different levels of serum insulin casts doubt on the use of urinary insulin concentration or excretion as a measure of serum insulin concentration. Repeated measurement of endogenous creatinine clearance during a glucose tolerance test showed no significant variation. All the results are summarized in Table IV, but broad relationships are more easily understood from Figure 3 , in which the results from Subject 16 are presented.

Renal disease. Table $\mathrm{V}$ shows the variations in serum and urinary insulin concentrations, urinary insulin clearance, and blood glucose in six fasting patients with renal disease (Patients 18 to 23 in Table III) who received $50 \mathrm{~g}$ of glucose by mouth. The striking difference between these results and those obtained in normal individuals is the higher values for urinary insulin concentration and urinary insulin clearance in patients with tubular disease. The differences are all the more marked when urinary clearance is expressed as a percentage of glomerular filtration rate (Table VI).

In a 50-year-old man with cadmium nephropathy (Patient 24, Table III), it was possible to measure only the insulin content of a 24-hour urine specimen. The diet during the collection period was uncontrolled. The total urinary insulin was $475,500 \mu \mathrm{U}$ per 24 hours. The expected amount in a normal individual of the same body weight would be in the range of 10 to $20,000 \mu \mathrm{U}$ per 24 hours according to the work of McArthur and Stimmler (10). 
TABLE V

Responses of patients with renal disease to a 50-g oral glucose load

\begin{tabular}{|c|c|c|c|c|c|c|c|}
\hline Patient & $\begin{array}{l}\text { Time after } \\
\text { oral glucose }\end{array}$ & $\begin{array}{c}\text { Blood } \\
\text { glucose }\end{array}$ & $\begin{array}{c}\text { Serum } \\
\text { insulin }\end{array}$ & $\begin{array}{l}\text { Urine } \\
\text { insulin }\end{array}$ & $\begin{array}{l}\text { Urine } \\
\text { flow rate }\end{array}$ & $\begin{array}{l}\text { Insulin } \\
\text { U/S ratio }\end{array}$ & $\begin{array}{l}\text { Urinary } \\
\text { insulin } \\
\text { clearance }\end{array}$ \\
\hline v & $\min$ & $\mathrm{mg} / 100 \mathrm{ml}$ & & & $m l / \min$ & & $\mathrm{ml} / \mathrm{min}$ \\
\hline 18 & $\begin{array}{c}0 \\
0-30 \\
30-60 \\
60-90 \\
90-120 \\
120-150\end{array}$ & $\begin{array}{r}84 \\
98 \\
113 \\
102 \\
80 \\
65\end{array}$ & $\begin{array}{l}23 \\
42 \\
80 \\
74 \\
41 \\
19\end{array}$ & $\begin{array}{r}280 \\
440 \\
1,730 \\
1,480 \\
700 \\
170\end{array}$ & $\begin{array}{l}0.60 \\
2.30 \\
2.50 \\
2.00 \\
2.20 \\
2.17\end{array}$ & $\begin{array}{r}12.2 \\
10.5 \\
21.6 \\
20.0 \\
17.1 \\
9.0\end{array}$ & $\begin{array}{r}7.3 \\
22.0 \\
54.0 \\
40.0 \\
37.6 \\
19.5\end{array}$ \\
\hline 19 & $\begin{array}{l}0 \\
0-30 \\
30-60 \\
60-90 \\
90-120\end{array}$ & $\begin{array}{r}74 \\
90 \\
121 \\
143 \\
130\end{array}$ & $\begin{array}{r}15 \\
35 \\
82 \\
111 \\
95\end{array}$ & $\begin{array}{r}1,200 \\
460 \\
1,030 \\
780 \\
460\end{array}$ & $\begin{array}{c}* \\
5.50 \\
3.17 \\
6.67 \\
10.00\end{array}$ & $\begin{array}{r}80.00 \\
13.14 \\
12.56 \\
7.03 \\
4.84\end{array}$ & $\begin{array}{c}* \\
72.3 \\
39.8 \\
46.8 \\
48.4\end{array}$ \\
\hline 20 & $\begin{array}{l}0 \\
0-30 \\
30-60 \\
60-90 \\
90-120\end{array}$ & $\begin{array}{r}60 \\
93 \\
121 \\
109 \\
86\end{array}$ & $\begin{array}{l}10 \\
33 \\
66 \\
78 \\
61\end{array}$ & $\begin{array}{r}25 \\
61 \\
130 \\
156 \\
106\end{array}$ & $\begin{array}{l}2.15 \\
1.27 \\
0.60 \\
1.17 \\
0.73\end{array}$ & $\begin{array}{l}2.50 \\
1.85 \\
1.97 \\
2.00 \\
1.74\end{array}$ & $\begin{array}{l}5.38 \\
2.35 \\
1.18 \\
2.34 \\
1.27 \\
2.50\end{array}$ \\
\hline 21 & $\begin{array}{l}0 \\
0-30 \\
30-60 \\
60-90 \\
90-120\end{array}$ & $\begin{array}{l}65 \\
75 \\
92 \\
91 \\
72\end{array}$ & $\begin{array}{l}19 \\
48 \\
84 \\
78 \\
53\end{array}$ & $\begin{array}{r}30 \\
35 \\
87 \\
125 \\
116\end{array}$ & $\begin{array}{l}0.47 \\
0.77 \\
0.27 \\
0.47 \\
0.47\end{array}$ & $\begin{array}{l}1.58 \\
0.73 \\
1.04 \\
1.60 \\
2.19\end{array}$ & $\begin{array}{l}0.74 \\
0.56 \\
0.26 \\
0.64 \\
0.76\end{array}$ \\
\hline 22 & $\begin{array}{l}0 \\
0-30 \\
30-60 \\
60-90 \\
90-120\end{array}$ & $\begin{array}{l}106 \\
131 \\
164 \\
150 \\
109\end{array}$ & $\begin{array}{l}22 \\
42 \\
64 \\
50 \\
26\end{array}$ & $\begin{array}{l}18 \\
21 \\
46 \\
44 \\
30\end{array}$ & $\begin{array}{l}0.97 \\
0.73 \\
0.70 \\
0.90 \\
0.73\end{array}$ & $\begin{array}{l}0.82 \\
0.50 \\
0.72 \\
0.89 \\
1.15\end{array}$ & $\begin{array}{l}0.80 \\
0.37 \\
0.50 \\
0.81 \\
0.84\end{array}$ \\
\hline 23 & $\begin{array}{l}0 \\
0-30 \\
30-60 \\
60-90 \\
90-120\end{array}$ & $\begin{array}{r}80 \\
120 \\
174 \\
168 \\
130\end{array}$ & $\begin{array}{l}20 \\
38 \\
55 \\
53 \\
40\end{array}$ & $\begin{array}{l}22 \\
18 \\
40 \\
40 \\
43\end{array}$ & $\begin{array}{l}1.47 \\
1.23 \\
0.97 \\
1.07 \\
1.73\end{array}$ & $\begin{array}{l}1.10 \\
0.47 \\
0.73 \\
0.76 \\
1.08\end{array}$ & $\begin{array}{l}1.62 \\
0.58 \\
0.71 \\
0.81 \\
1.87\end{array}$ \\
\hline
\end{tabular}

* Timed urine not available.

\section{Discussion}

The insulin extraction ratio of $0.29 \pm 0.12$ (SD), obtained from the renal arteriovenous difference studies in patients with normal renal function, implies that the renal extraction of insulin is of the order of $190 \mathrm{ml}$ per minute, assuming a normal renal plasma flow of $650 \mathrm{ml}$ per minute. This figure is significantly greater than an average normal value for glomerular filtration rate of approximately $120 \mathrm{ml}$ per minute. It follows that the whole of the renal clearance of insulin cannot be due to loss by glomerular filtration, even if insulin passes the glomerular membrane as freely as water. It is necessary, therefore, to postulate either tubular secretion of insulin into the urine or metabolic consumption of insulin by renal tis- sue. The urinary insulin clearance, calculated from the ratio of urinary to serum concentration and urine flow rate, had an over-all mean value of $0.37 \mathrm{ml}$ per minute in nine fasting individuals

TABLE VI

The relationship of urinary insulin clearance to $G F R$ in patients with renal disease

\begin{tabular}{ccc}
\hline \hline & $\begin{array}{c}\text { Mean urinary } \\
\text { Patient }\end{array}$ & \begin{tabular}{c} 
Urinary insulin clearance \\
\cline { 3 - 3 } insulin clearance
\end{tabular} \\
\hline & ml $/$ min & GFR \\
18 & 30.10 & 75.25 \\
19 & 51.80 & 136.32 \\
20 & 2.50 & 10.40 \\
21 & 0.59 & 14.75 \\
22 & 0.66 & 0.83 \\
23 & 1.12 & 4.15
\end{tabular}


with normal renal function. Thus, there can be no net excretion of insulin by the tubules, although some minor degree of tubular secretion cannot be excluded. There must, therefore, be considerable metabolic consumption of insulin by the kidney analogous to that demonstrated for the liver by Samols and Ryder (17). Assuming a mean serum insulin throughout the day of $14 \mu \mathrm{U}$ per $\mathrm{ml}$ (the midpoint of our normal fasting range), the renal extraction of insulin calculated above would imply a daily renal consumption of insulin of approximately $4 \mathrm{U}$. This is to be seen in the context of a total daily insulin requirement of 26 to $40 \mathrm{U}$ for pancreatectomized man (18).

There are three possible explanations for the very small amounts of insulin appearing in the urine of normal individuals; either filtration at the glomerulus is much less than would be predicted on theoretical grounds (19) because of polymerization or protein binding, or there is very efficient tubular reabsorption of filtered insulin, or filtered insulin is largely destroyed within the tubular lumen. If the second alternative is true and the majority of filtered insulin is reabsorbed, then the figures for renal arteriovenous differences show that reabsorbed insulin does not return to the renal vein.

The permeability of the glomerular basement membrane to insulin is theoretically determined on the basis of molecular size. The molecular weight of insulin has been a matter of considerable conjecture (20), but there is now general agreement on a molecular weight of 6,000 with existence in serum possibly as a dimer or other small number polymer, which would not be impeded at the glomerulus. Binding of insulin by serum proteins was studied in vitro by Merimee, Lockwood, and Prout (21), who found slight (approximately 5\%) binding of ${ }^{131} \mathrm{I}$-labeled insulin by all protein fractions and rather greater affinity for alpha globulins. These questions of protein binding and polymerization would be of relevance were it not that large quantities of insulin are found in the urine of patients with severe impairment of renal tubular function. In such patients the urinary insulin clearance may approach the glomerular filtration rate (Table VI). Values for urinary insulin clearance in Tables IV, V, and VI will be slightly too high because they are calculated from peripheral venous rather than arterial insulin concentra- tions. This probably accounts for urinary insulin clearance exceeding glomerular filtration rate in Patient 19. The conclusion is that insulin is normally totally filtered at the glomerulus and is then almost completely reabsorbed or destroyed within the tubules. The reabsorptive or destructive process is such that over $98 \%$ of filtered insulin is accounted for at all serum insulin concentrations encountered after an oral glucose load. In tubular disease the efficiency of the process falls and, as in Patients 18 and 19, the amount of insulin excreted in the urine may eventually approach that filtered. Thus, of the insulin consumed by the kidney, which in the fasting state amounts to some $29 \%$ of the insulin in renal arterial blood in each passage, slightly more than half is first filtered at the glomeruli, whereas the remainder is taken up directly from the blood. The possibility that increased permeability of the glomerular basement membrane is the mechanism of the increased insulinuria of renal disease is made unlikely by the finding of normal or near normal urinary insulin clearances in Patients 22 and 23 with nephrotic syndrome, in whom glomerular permeability was certainly increased.

Injected insulin is known to accumulate in the cells of the proximal renal tubules (22), and these cells have a high content of insulinase (23). The proximal tubule is also the site of glucose reabsorption, and it has been suggested that filtered insulin facilitates the reabsorption of filtered glucose (22). In Patients 18 and 19 with severe tubular disorders in whom almost the whole of the filtered insulin was lost in the urine, there was only a trace of glycosuria; the great majority of the filtered glucose was still reabsorbed. It may be that filtered insulin is necessary for the reabsorption of filtered glucose, but the magnitude of the filtered load of glucose cannot be the prime determinant of insulin reabsorption. Even if the suggested variation of urinary insulin clearance after glucose load is a valid observation and urinary insulin clearance may vary in normal individuals by as much as a factor of eight, such variations can be of no importance in over-all insulin economy because tubular reabsorption or destruction is at all times over $98 \%$ efficient. The greatest amount of insulin found in the urine of a normal individual was $1.47 \%$ of the calculated filtered load. It is not known whether the renal insulin extraction is 
altered in the presence of tubular disease, nor has the renal or urinary insulin clearance been measured in the diabetic or the patient with renal glycosuria.

Table VI shows how the renal handling of insulin differs from normal in particular renal disorders. The urinary insulin clearance equaled or approached glomerular filtration rate in the two patients with Fanconi syndrome whose disease was predominantly tubular, and the value was some 25 times greater than normal (as a proportion of glomerular filtration rate) in the patient recovering from acute tubular necrosis. Patient 24 with cadmium nephropathy, where the disease is almost exclusively tubular (24), had approximately 25 times more insulinuria than normal. These findings contrast with the normal urinary insulin clearance, both absolutely and as a proportion of glomerular filtration rate, in Patient 22 with nephrotic syndrome. This patient had a "minimal" glomerular abnormality (25) and no tubular lesion. Insulin clearance was slightly increased in Patient 23 also with nephrotic syndrome with a predominantly minimal glomerular lesion, but in this case there had been several authenticated episodes of pyelonephritis and presumably an added tubular lesion. In patient 21 the urinary insulin clearance relative to glomerular filtration rate was considerably increased to a value intermediate between that seen in the purely glomerular disease of "minimal" nephrotic syndrome and the purely tubular Fanconi syndrome. This patient suffered from chronic glomerulonephritis but had entered terminal chronic renal failure where glomerular and tubular disorder inevitably coexist.

These results demonstrate that the reabsorption or destruction of insulin by the normal renal tubules is a very efficient process. It follows that measurement of this capacity may afford a very sensitive measure of tubular function. As insulin assay becomes reliable and readily available, so urinary insulin clearance may achieve some usefulness as a sensitive test of proximal tubular function.

Caution must be exercised in attempting to use urinary insulin concentration or excretion as an index of serum insulin concentration or insulin production, because the proportion of the filtered load of insulin appearing in the urine is very small whatever the serum level and the absolute amount of insulin in the urine is at all times small. Furthermore, major changes in urinary insulin excretion may occur as a result of relatively minor and otherwise undetected renal tubular abnormalities.

The validity of these conclusions is necessarily dependent on the accuracy of the insulin assay. Under fasting conditions in normal individuals urinary insulin concentrations and renal arteriovenous insulin differences are often near the limit of the sensitivity and reproducibility of this assay method. In the range 0 to $5 \mu \mathrm{U}$ per $\mathrm{ml}$, individual assays may have an error $(2 \times$ standard deviation) of around $70 \%$. For this reason it is not possible to regard urinary insulin clearances and renal insulin extraction ratios for individual patients as accurate physiological measurements. However, the variation of urinary insulin clearance in the group of nine normal subjects was small (range 0.06 to 0.61 , mean $0.37 \pm 0.18 \mathrm{SD}$ ) and allows us to be reasonably certain that the results obtained are of the right order of magnitude. The urinary insulin clearance of patients with severe tubular disease, when expressed as a fraction of glomerular filtration rate, differs from that of normal individuals by factors of 30 to 400 . Conclusions about the filtration of insulin and its subsequent tubular reabsorption or destruction are largely based on such differences, which are fortunately so great that they are unlikely to be due to errors of the assay. As to the precise magnitude of the renal insulin extraction ratio and the question of whether this always exceeds the filtration fraction, the evidence presented here can only be regarded as suggestive rather than conclusive. The assay used in this study is as sensitive as any known to exist; the precise measurement of the renal handling of insulin must await an assay with sensitivity increased at least tenfold. Meanwhile, it may be of value to infer the mode of handling from the evidence now available.

\section{Acknowledgments}

We are grateful to Drs. N. Segal and D. W. Evans who performed the renal vein catheterizations, the physicians of the Queen Elizabeth Hospital, Birmingham, who allowed us to study their patients, and Miss Jean Fowler for assistance with the insulin assays. 


\section{References}

1. O'Brien, J. P., and A. R. Sharpe, Jr. Abnormal carbohydrate metabolism in renal failure. Metabolism 1965, 14, 1294.

2. Runyan, J. W., Jr., D. Huritz, and S. L. Robbins. Effect of Kimmelstiel-Wilson syndrome on insulin requirements in diabetes. New Engl. J. Med. 1955, 252, 388.

3. Epstein, F. H., and V. J. Zupa. Clinical correlates of the Kimmelstiel-Wilson lesion. New Engl. J. Med. 1956, 254, 896.

4. Kalant, N., M. Clamen, and M. M. Hoffman. Effect of experimental nephrosis on alloxan diabetes in rats. Diabetes 1958, 7, 140.

5. Hampers, C. L., J. S. Soeldner, P. B. Doak, and J. P. Merrill. Effect of chronic renal failure and hemodialysis on carbohydrate metabolism. J. clin. Invest. 1966, 45, 1719.

6. Hutchings, R. H., R. M. Hegstrom, and B. H. Scribner. Glucose intolerance in patients on longterm intermittent dialysis. Ann. intern. Med. 1966, 65, 275.

7. Bott, P. A., and A. N. Richards. The passage of protein molecules through the glomerular membranes. J. biol. Chem. 1941, 141, 291.

8. Vogel, J. M., and K. G. Scott. The clearance of insulin by the kidney. Fed. Proc. 1962, 21, 203.

9. Jørgensen, K. R. Immunoassay of insulin in human urine. Acta endocr. (Kbh.) 1966, 51, 400.

10. McArthur, R. G., and L. Stimmler. Urinary insulin excretion in healthy children and in siblings of childhood-onset diabetics. Lancet 1966, 1, 1236.

11. Lowy, C., A. H. Rubinstein, A. D. Wright, T. J. Martin, and T. R. C. Fraser. Urinary immunochemical insulin in normal, obese, obese diabetic subjects during oral glucose tolerance test and starvation. Diabetologia 1966, 2, 209.

12. Morgan, C. R., and A. Lazarow. Immunoassay of insulin using a two-antibody system. Proc. Soc. exp. Biol. (N. Y.) 1962, 110, 29.

13. Middleton, J. E., and W. J. Griffiths. Rapid colorimetric micro-method for estimating glucose in blood and C.S.F. using glucose oxidase. Brit. med. J. 1957, 2, 1525.

14. Butler, E. A., F. V. Flynn, H. Harris, and E. B. Robson. A study of urine proteins by two dimensional electrophoresis with special reference to the proteinuria of renal tubular disorders. Clin. chim. Acta 1962, 7, 34.

15. Butterfield, W. J. H., C. J. Garratt, and M. J. Whichelow. Peripheral hormone action: studies on the clearance and effect of [ $\left.{ }^{121} \mathrm{I}\right]$ iodo-insulin in the peripheral tissues of normal acromegalic and diabetic subjects. Clin. Sci. 1963, 24, 331.

16. Rabinowitz, D., and K. L. Zierler. A metabolic regulating device based on the actions of human growth hormone and of insulin, singly and together, on the human forearm. Nature (Lond.) 1963, 199, 913.

17. Samols, E., and J. A. Ryder. Studies on tissue uptake of insulin in man using a differential immunoassay for endogenous and exogenous insulin. $\mathrm{J}$. clin. Invest. 1961, 40, 2092.

18. Marble, A. The physiology of diabetes in The Treatment of Diabetic Mellitus. 8th ed., E. P. Joslin, H. F. Root, P. White, and A. Marble, Eds. London, Kimptom, 1947, p. 139.

19. Hardwicke, J., and J. F. Soothill. Glomerular damage in terms of pore size in Renal Biopsy: Clinical and Pathological Significance. Ciba Foundation Symposium, G. E. W. Wolstenholme and M. P. Cameron, Eds. London, J. \& A. Churchill, 1961, p. 32.

20. Gutfreund, H. An Introduction to the Study of Enzymes. Oxford, Blackwell, 1965, p. 174.

21. Merimee, T. J., D. H. Lockwood, and T. E. Prout. The relationship of insulin I- ${ }^{181}$ to serum protein fractions. Bull. Johns Hopk. Hosp. 1965, 116, 191.

22. Darmady, E. M. Correlation of renal function and structure. J. clin. Path. 1965, 18, 493.

23. Mirsky, I. A., and R. H. Broh-Kahn. The inactivation of insulin by tissue extracts. I. The distribution and properties of insulin inactivating extracts (insulinase). Arch. Biochem. 1949, $20,1$.

24. Kazantes, G., F. V. Flynn, J. S. Spowage, and D. G. Trott. Renal tubular malfunction and pulmonary emphysema in cadmium pigment workers. Quart. J. Med. 1963, 32, 165.

25. Blainey, J. D., D. B. Brewer, J. Hardwicke, and J. F. Soothill. The nephrotic syndrome. Diagnosis by renal biopsy and biochemical and immunological analyses related to the response to steroid therapy. Quart. J. Med. 1960, 29, 235. 